\title{
The effect of the density of flowering individuals on the mating systems of nine tropical tree species
}

\author{
D. A. MURAWSKI \& J. L. HAMRICK \\ Departments of Botany and Genetics, The University of Georgia, Athens, GA 30602, U.S.A.
}

\begin{abstract}
Mating systems were examined through allozyme analysis for nine tropical tree species that occur on Barro Colorado Island, Republic of Panama. Estimates of outcrossing rates, using a mixed mating model, ranged from 0.35 to 1.08 . Most species were highly outcrossed but two species that occurred at low densities had outcrossing rates below 0.7 . Heterogeneity among trees in pollen allele frequencies contributing to progeny arrays was significant. The degree of heterogeneity in pollen allele frequencies was measured by Wright's $F_{\mathrm{ST}}$, treating progeny arrays as populations. Mean $F_{\mathrm{ST}}$ values were negatively correlated with flowering tree density, which indicates that trees at low density sample pollen from fewer individuals than trees in denser populations. Among-year heterogeneity in pollen allele frequencies for two species was also related to the density of flowering individuals; years with lower flowering tree density had greater heterogeneity and/or more selfing. These results indicate that several population parameters, such as inbreeding, genetic relatedness of progeny arrays, gene flow and effective population size are associated with the density of flowering individuals and thus vary from year to year and among locations.
\end{abstract}

Keywords: Allozyme analysis, mating systems, Panama, tropical trees, tree density.

\section{Introduction}

Plant mating systems can be measured as the proportion of matured seeds that result from outcrossing events. Many tropical tree species possess mechanisms that ensure or encourage outcrossing (e.g. Kalin Arroyo, 1976, 1979; Chan, 1981; Koptur, 1984; Bawa et al., Dayanandan, et al., 1990). Allozyme analyses of progeny arrays have demonstrated that tropical tree mating systems range from mixed outcrossing and selfing, as in Cavanillesia platanifolia (Murawski et al., 1990), to predominantly or completely outcrossing as in Pithecellobium pedicellare (O'Malley \& Bawa, 1987), Bertholletia excelsa (O'Malley et al., 1988), and Quararibea asterolepis (Murawski et al., 1990).

The degree of outcrossing for hermaphroditic plants depends on factors such as: the presence and intensity of self-incompatability mechanisms; the degree of protogyny or protandry; foraging behaviour of pollinators within and among plants; and selective abortion of selfed fruit or seed. Flowering plant density should also be a prime determinant of pollinator foraging

Correspondence: Dr. D. A. Murawski, Department of Biology, University of Massachusetts at Boston, Boston, MA, 02125, U.S.A. behaviour and therefore could have important consequences in terms of the breeding structure of a plant population (Levin \& Kerster, 1974). For example, in a low density population of the Bombacaceous tree, Cavanillesia platanifolia, there was a positive correlation between flowering tree density and outcrossing rate (Murawski et al., 1990). In that study, isolated trees were highly or completely selfed, which indicates low levels of interplant movement by the pollinators. Other studies have related outcrossing rates to density. Schemske \& Lande (1985) list examples of environmentally determined outcrossing rates for three plant species due either to flower density or to pollinator abundance (see also Ellstrand et al., 1978).

Tropical forests show a wide range of tree densities, although most species exist at very low densities (Ashton, 1988; Hubbell \& Foster, 1986). Within populations, species may vary greatly in the proportion of adults that reproduce within a season, or even the degree of synchrony in flowering times. Such variation in flowering plant density should affect several aspects of a species' breeding structure. In this paper, we examine how adult or flowering tree density is related to the degree of outcrossing and to the genetic composition of pollen received by individual trees. 
We present data on outcrossing rates using allozyme analyses of progeny arrays of nine tropical rain forest tree species. In addition, we address the following questions.

1 Are population outcrossing rates related to the density of flowering trees?

2 Are maternal trees receiving a random sample of pollen from trees in the study site? Given a negative answer to question (2) then,

3 are adult trees at low densities receving a genetically more heterogeneous sample of pollen than trees with higher densities?

The latter question is addressed by examining the heterogeneity in allele frequencies of pollen recived by individuals belonging to populations that differ in adult densities.

\section{Materials and methods}

The study site was Barro Colorado Island (BCI), located in Gatun Lake, Republic of Panama. Most collections were made on a 50 ha Forest Dynamics Plot
(FDP) established by S. Hubbell and R. Foster in which all trees and shrubs with a stem diameter greater than $1 \mathrm{~cm}$ were tagged and mapped.

Nine species contribute to the present study (Table 1). Six new species were examined for their mating systems for this study: Beilschmedia pendula (S.W.) Hemsl., Brosimum alicastrum Sw. subsp. bolivarense (Pitt.) C. C. Berg, Ceiba pentandra (L.) Gaertn., Playtpodium elegans J. Vogel, two populations of Sorocea affinis Hemsl. with different densities, and Trichilia tuberculata C. DC. The other three species previously examined for mating system from the same study site include: Cavanillesia platanifolia (H. \& B.) H.B.K. and Quararibea asterolepis Pitt. (Murawski et. al., 1990), and Tachigali versicolor Standl. \& L.O. Wms (M. D. Loveless and J. L. Hamrick, in preparation). All species typically have single-seeded fruit except Trichilia, which usually has one to three seeds per fruit. All species have a seasonal mass-flowering phenology. Species were chosen for mating system analysis opportunistically, because they are hermaphroditic and the mating system is unknown, or because they were shown previously to exhibit sufficient allozyme polymorphism for such an analysis .

Table 1 Study species and their characteristics

\begin{tabular}{|c|c|c|c|c|}
\hline Family & Species & Height & $\begin{array}{l}\text { Sexual } \\
\text { system }\end{array}$ & $\begin{array}{l}\text { Floral } \\
\text { visitors }\end{array}$ \\
\hline \multirow[t]{3}{*}{ Bombacaceae } & $\begin{array}{l}\text { Cavanillesia } \\
\text { platanifolia }\end{array}$ & Canopy & $\mathrm{H}$ & $\begin{array}{l}\text { Hawmoths*, } \\
\text { monkeys, bats, } \\
\text { bees, birds }\end{array}$ \\
\hline & $\begin{array}{l}\text { Ceiba } \\
\quad \text { pentandra }\end{array}$ & Canopy & $\mathbf{H}$ & $\begin{array}{l}\text { Bats } \dagger, \text { birds, } \\
\text { bees, beetles, } \\
\text { Wasps, mammals } \ddagger\end{array}$ \\
\hline & $\begin{array}{l}\text { Quararibea } \\
\text { asterolepis }\end{array}$ & Canopy & $\mathbf{H}$ & $\begin{array}{l}\text { Hawkmoths, } \\
\text { monkey, bats }\end{array}$ \\
\hline \multirow[t]{2}{*}{ Fabaceae } & $\begin{array}{l}\text { Platypodium } \\
\text { elegans }\end{array}$ & Canopy & $\mathbf{H}$ & Bees \\
\hline & $\begin{array}{l}\text { Tachigali } \\
\quad \text { versicolor }\end{array}$ & Canopy & $\mathrm{H}$ & Bees \\
\hline Lauraceae & $\begin{array}{l}\text { Beilschmedia } \\
\text { pendula }\end{array}$ & Canopy & $\mathrm{H}$ & $\begin{array}{l}\text { Not observed } \\
\text { Bees? }\end{array}$ \\
\hline Meliaceae & $\begin{array}{l}\text { Trichilia } \\
\quad \text { tuberculata }\end{array}$ & Canopy & $\mathrm{H}$ & $\begin{array}{l}\text { Not observed } \\
\text { Bees? }\end{array}$ \\
\hline \multirow[t]{2}{*}{ Moraceae } & $\begin{array}{l}\text { Brosimum } \\
\quad \text { alicastrum }\end{array}$ & Canopy & GD§ & Bees, wind \\
\hline & $\begin{array}{l}\text { Sorocea } \\
\quad \text { affinis }\end{array}$ & $\begin{array}{l}\text { Under- } \\
\text { story }\end{array}$ & D & $\begin{array}{l}\text { Small bees, } \\
\text { and wind }\end{array}$ \\
\hline
\end{tabular}

*From Murawski et al., (1990).

†From Baker \& Harris (1959), Carvalho (1960).

†From Toledo (1977).

$\S$ Reportedly gynodioecious, although no bisexual trees have been observed in our study site (R. Foster and Bonifacio de Leon, personal communication).

$\mathrm{H}=$ hermaphroditic, $\mathrm{GD}=$ gynodioecious, $\mathrm{D}=$ dioecious . 
Fruit were picked directly from trees (Sorocea) or collected from seed shadows beneath maternal trees (all other species). Care was taken to avoid collecting seeds from overlapping seed shadows. Large progeny sample sizes were collected in order to improve estimates of pollen allele frequencies. If fruit were multiple-seeded, one seed was sampled per fruit to avoid biasing the data progeny of correlated mating events.

Seeds were collected from all fruiting trees (Platypodium, Brosimum) on the FDP or from a representative sample of trees (Beilschmedia, Trichilia and Quararibea). The study area was expanded for the three rarest species, Cavanillesia, Ceiba, and Tachigali, to include all known fruiting trees on BCI. Two 1-ha plots within the FDP, which differed in the density of adult trees, were examined for the understory tree Sorocea. Cavanillesia was sampled for three consecutive years (1987-1989) and Platypodium for two consecutive years (1988-1989). The density of flowering trees was noted for Cavanillesia, Ceiba, Platypodium, Sorocea, and Tachigali.

Seeds were either lyophilized (Sorocea, Cavanillesia, Platypodium, and Trichilia) or germinated in a greenhouse. If germinated in Panama, the seedling leaves were lyophilized (Cavanillesia, Platypodium, Quararibea, Sorocea, and Tachigali) and shipped to Georgia for ultracold storage prior to enzyme extraction. Brosimum and Beilschmedia were germinated in the UGA Botany greenhouse and fresh seedling leaves were sampled for analysis.

Horizontal starch gel electrophoresis was used to assay seed or seedling allozymes. Between two and 10 loci were assayed to obtain outcrossing estimates (Table 2). All species exhibited diploid inheritance patterns as interpreted from genotypic frequencies of individual progeny arrays.

We used the multilocus mixed mating model of Ritland \& Jain (1981) to obtain: single locus and multilocus outcrossing estimates $(t)$, maternal genotypes, and pollen allele frequencies. Maternal genotypes were assessed directly from leaf material collected from maternal trees of Platypodium and Sorocea. Standard errors of the outcrossing estimates were calculated using the bootstrap method (as in Ritland, 1990) where the sampling unit is among families if the number of families analysed exceeds 20 or is within families if there are fewer than 20 families per population. Five hundred bootstraps were specified to obtain each variance estimate. The outcrossing rate of Tachigali was estimated using the multilocus mixed mating model of Shaw et al. (1981).

One of the major assumptions of the Ritland and Jain model, random mating among individuals, was
Table 2 Buffer system and isozyme loci utilized for the study species. Buffer recipes were as in Soltis et al.(1983)

\begin{tabular}{lll}
\hline \multirow{2}{*}{ Species } & $\begin{array}{l}\text { Gel and electrode } \\
\text { buffer system }\end{array}$ & Loci \\
\hline Beilschmedia & 2 & IDH-1, IDH-2, PGI \\
Brosimum & 6 modified & FE-2, PGI, TO \\
& 4 & 6P-2, 6P-3, IDH \\
& 8 modified & TPI-1 \\
Cavanillesia & 2 & IDH, PGI, MDH \\
& 6 modified & PGM, FE, TPI \\
Ceiba & 2 & PGI \\
& 6 modified & PGM-1, PGM-2, TPI-3, \\
& & TPI-4 \\
Platypodium & 6 modified & AAT \\
& 8 modified & TPI-2, TPI-3, CE \\
& 2 & DIA, GOT, FE-1, FE-2, \\
& 2 FE-4, BGAL \\
Quararibea & 6 modified & PGI \\
& 8 modified & PGM-1, PGM-2, PGI \\
Sorocea & 6 modified & PGM-1, PGM-2 \\
& 11 & IDH, AK \\
Tachigali & 4 & DIA-2 \\
Trichilia & 4 & IDH, DIA-1 \\
& 11 & MDH \\
& 6 modified & TPI \\
& 2 & PGI \\
\hline
\end{tabular}

tested using chi-square tests of heterogeneity of pollen allele frequencies contributing to seed or seedling genotype of different maternal trees. Pollen allele frequencies were obtained assuming normal Mendelian segregation of maternal alleles. Thus, the maternal allele contribution to the progeny was subtracted from the progeny genotypes to obtain pollen allele frequencies. For all hermaphroditic species with outcrossing estimates of less than 100 per cent, maternal trees with the same genotypes at any given locus were compared with each other in order to test for heterogeneity in outcross pollen allele frequencies received by individual trees. Loci were examined for which the frequency of the common allele did not exceed 0.9 .

Treating progeny arrays as subpopulations, among tree diversity in pollen allele frequencies contributing to seed/seedlings was examined using Wright's $F_{\mathrm{ST}}$. An $F_{\mathrm{ST}}$ value was calculated for each locus based on, $F_{\mathrm{ST}}=\sigma^{2} /\left(p_{i}\left[1-p_{i}\right]\right)$, where $\sigma^{2}$ is the variance in pollen allele frequencies among seed trees, and $p_{i}$ is the frequency of the $i$ th pollen allele averaged over all maternal trees. $F_{\mathrm{ST}}$ values were calculated on families with a minimum sample size of 25 progeny.

Species and populations were ranked by density of reproductive individuals. The actual or estimated 
density of flowering or fruiting trees on the 50-ha plot was used to designate a particular rank. The density estimate was halved for the dioecious gynodioecious species.

\section{Results}

Trichilia, Sorocea, and Quararibea appear to be completely outcrossed (Table 3 ). Other species have outcrossing rates ranging from 0.213 to 0.937 . Brosimum, Cavanillesia, and Ceiba, with outcrossing estimates lower than 0.9 were also tested for an excess frequency of multilocus genotypes identical to the maternal tree in the potentially selfed progeny (as in Murawski $e t$ al., 1990), would indicate apomixis by sporophytic agamospermy. No excess was observed, and as a result, apomixis can be ruled out as contributing to the apparent selfing rate for those species.

When outcrossing rates are plotted against flowering tree density for each species an apparent relationship exists (Fig. 1). The rank correlation of $t_{\mathrm{m}}$ (using the mean $t_{\mathrm{m}}$ for species represented by more than 1 year or site) with flowering tree density is significant
(Spearman's rho $=0.717$, d.f. $=7, P<0.05$ ). This relationship is largely due to the three representatives of the Bombacaceae (Canvanillesia, Ceiba, and Quararibea). No relationship of flowering tree density and outcrossing rate exists for the other six species.

Significant differences in allele frequencies of pollen received by different maternal trees were observed in all species and for most loci (chi-squared tests of heterogeneity for each locus, $P<0.05$ for 79 per cent of the cases). These tree species are not mating (or more specifically, not outcrossing) at random, but are sampling pollen from a diverse subset of the available flowering trees.

A grand mean of the $F_{\mathrm{ST}}$ values was calculated for species represented by more than 1 year or site (Cavanillesia, Platypodium, and Sorocea). The rank correlation of the mean $F_{\mathrm{ST}}$ value for each of the nine species with the density of flowering trees was negative and significant (Spearman's rho $=-0.738$, d.f. $=7$, $P<0.05)$. Significant differences were also seen among $F_{\text {ST }}$ values of species analysed in more than one year or site. Platypodium had a significantly higher average $F_{\mathrm{ST}}$

Table 3 Mutilocus outcrossing rates $\left(t_{\mathrm{m}}\right)$ and degree of variation in incoming pollen allele frequencies among maternal trees $\left(F_{\mathrm{SF}}\right)$ for the nine study tree species in Barro Colorado Island. $F_{\mathrm{SF}}$ is averaged over all loci. The densities of flowering trees and adult-size trees in the 50-ha plot are also given

\begin{tabular}{|c|c|c|c|c|c|c|c|}
\hline Species & $\begin{array}{l}\text { Number of } \\
\text { maternal trees } \\
\text { sampled }\end{array}$ & $\begin{array}{l}\text { Mean number } \\
\text { of progeny } \\
\text { per tree }\end{array}$ & $\begin{array}{l}\text { Number of } \\
\text { loci }\end{array}$ & $\begin{array}{l}\text { Outcrossing rate } \\
\left(t_{\mathrm{m}}\right)( \pm \mathrm{SE})\end{array}$ & $\begin{array}{l}\text { Flowering tree } \\
\text { density per ha }\end{array}$ & $\begin{array}{l}\text { Adult* tree } \\
\text { density per } \\
\text { ha }\end{array}$ & Mean $F_{\mathrm{SF}}$ \\
\hline Beilschmedia & 14 & 26 & 3 & $0.918(0.058)$ & $2.10 \dagger$ & 2.36 & 0.064 \\
\hline Brosimum & 9 & 44 & 7 & $0.875(0.035)$ & $0.30^{\dagger}$ & 0.44 & 0.170 \\
\hline \multicolumn{8}{|l|}{ Cavanillesia } \\
\hline VL & 3 & 48 & 4 & $0.213(0.052)$ & $0.10(32 \ddagger)$ & 0.28 & 0.259 \\
\hline $\mathrm{L} \S$ & 11 & 45 & 5 & $0.347 \S(0.025)$ & $0.08(49 \ddagger)$ & 0.28 & 0.227 \\
\hline $\mathrm{H} \S$ & 20 & 72 & 4 & $0.569 \S(0.024)$ & $0.18(74 \ddagger)$ & 0.28 & 0.151 \\
\hline Ceiba & 12 & 44 & 6 & $0.689(0.032)$ & 0.24 & 0.50 & 0.151 \\
\hline \multicolumn{8}{|l|}{ Platypodium } \\
\hline $\mathrm{L}$ & 5 & 40 & $10^{* *}$ & $0.924(0.043)$ & 0.34 & 0.72 & 0.163 \\
\hline $\mathrm{H}$ & 5 & 31 & $10^{* *}$ & $0.898(0.043)$ & 0.50 & 0.72 & 0.083 \\
\hline $\begin{array}{l}\text { Quararibea§ } \\
\text { Sorocea }\end{array}$ & 27 & 34 & 5 & $1.008(0.010)$ & $2.00 \dagger$ & 7.28 & 0.098 \\
\hline L & 8 & 49 & 5 & $1.089(0.045)$ & 3.56 & $15.4 \dagger \dagger$ & 0.104 \\
\hline H & 7 & 71 & 5 & $0.969(0.020)$ & 6.51 & $15.4 \dagger \dagger$ & 0.083 \\
\hline Tachigaliłł & 23 & 44 & 2 & $0.937(0.044)$ & 0.10 & 0.16 & 0.108 \\
\hline Trichilia & 17 & 48 & 2 & 1 กา $(\cap \cap 28)$ & $6.00^{\dagger}$ & 10.1 & 0.082 \\
\hline
\end{tabular}

*Based on dbh of estimated adult size from the FDP.

$\uparrow$ Approximation based on density of fruiting trees.

$\ddagger$ Percentage of trees examined on entire island that flowered.

§Outcrossing rates from Murawski et al. (1990).

TOutcrossing rate from D. A. Murawski \& J. L. Hamrick (in preparation).

**Ten loci used to determine the outcrossing estimate; 14 loci used to determine $F_{\mathrm{ST}}$.

††Extrapolated for the 50-ha FDP plot. Each plot is only 1 ha in size, imbedded within the FDP plot.

¥łOutcrossing rate from M. D. Loveless \& J. L. Hamrick (in preparation).

$\mathrm{H}=$ High density, $\mathrm{M}=$ medium density, and $\mathrm{L}=$ Low density. 
for the year with few flowering trees (L, Fig. 1) than for the year with a higher density of flowering trees $(\mathrm{H}$, Fig. 1; Mann-Whitney $U$-test, $\quad P<0.05)$, which reinforces the negative correlation of $F_{\mathrm{ST}}$ with flowering tree density observed across all species. Cavanillesia shows a similar (although not significant) trend over the three consecutive years of study. It should be noted, however, that the year of very low density (VL, 1989) produced only three trees with fruit. Two of the three trees flowered in isolation and had no obvious outcrossed progeny, whereas the third tree overlapped in flowering time by a few days with a neighbouring tree less than $30 \mathrm{~m}$ away and produced some outcrossed fruit [23 per cent $(15 / 66)$ unambiguous outcrosses]. Therefore the heterogeneity in the mixed mating
Cavanillesia may be due more to variation in the rate of selfing than to outcrossing with few trees. The high and low density plots of Sorocea affinis did not differ significantly in $F_{\mathrm{ST}}$ values, although the trend was in the expected direction. Tachigali, with the lowest adult density, did not fit the pattern seen for the other species. However, flowering trees of Tachigli were clustered in the year of analysis (1984). The low average $F_{\mathrm{ST}}$ seen for this species might be due to relatively random mating within clusters. In addition, individual Tachigali flower for long periods of time and there is evidence that substantial levels of gene flow occur over distances of at least $500 \mathrm{~m}$ (M. D. Loveless and J. L. Hamrick, in preparation).

We could have assigned rank order to the species
Fig. 1 Multilocus outcrossing rate $( \pm$ $\mathrm{SE}$ ) relative to the density ranking of flowering trees for nine tropical tree species on Barro Colorado Island. The species are listed by three letter acronyms: Tachingali versicolor TAC, Cavanillesia platanifolia CAV ( 3 years: very low $\mathrm{VL}$, low $\mathrm{L}$ and high $\mathrm{H}$ density), Ceiba pentandra CEI, Brosimum alicastrum BRO, Platypodium elegans PLA (2 years: low $L$ and high $H$ density), Quararibea asterolepis QUA, Beilschmedia pendula BEI, Sorocea affinis SOR (low and high density sites), and Trichilia tuberculata TRI.

Fig. 2 The relationship between the degree of among-tree heterogeneity in incoming pollen allele frequencies as measured by $F_{\mathrm{ST}}$ values (means $\pm \mathrm{SE}$ ) and the relative density ranking of flowering trees of nine species on $\mathrm{BCl}$. The species ranks and names are as in Fig. 1. Because only two measurements were made on Tachiglai versicolor (TAC), a value for standard error was not calculated.
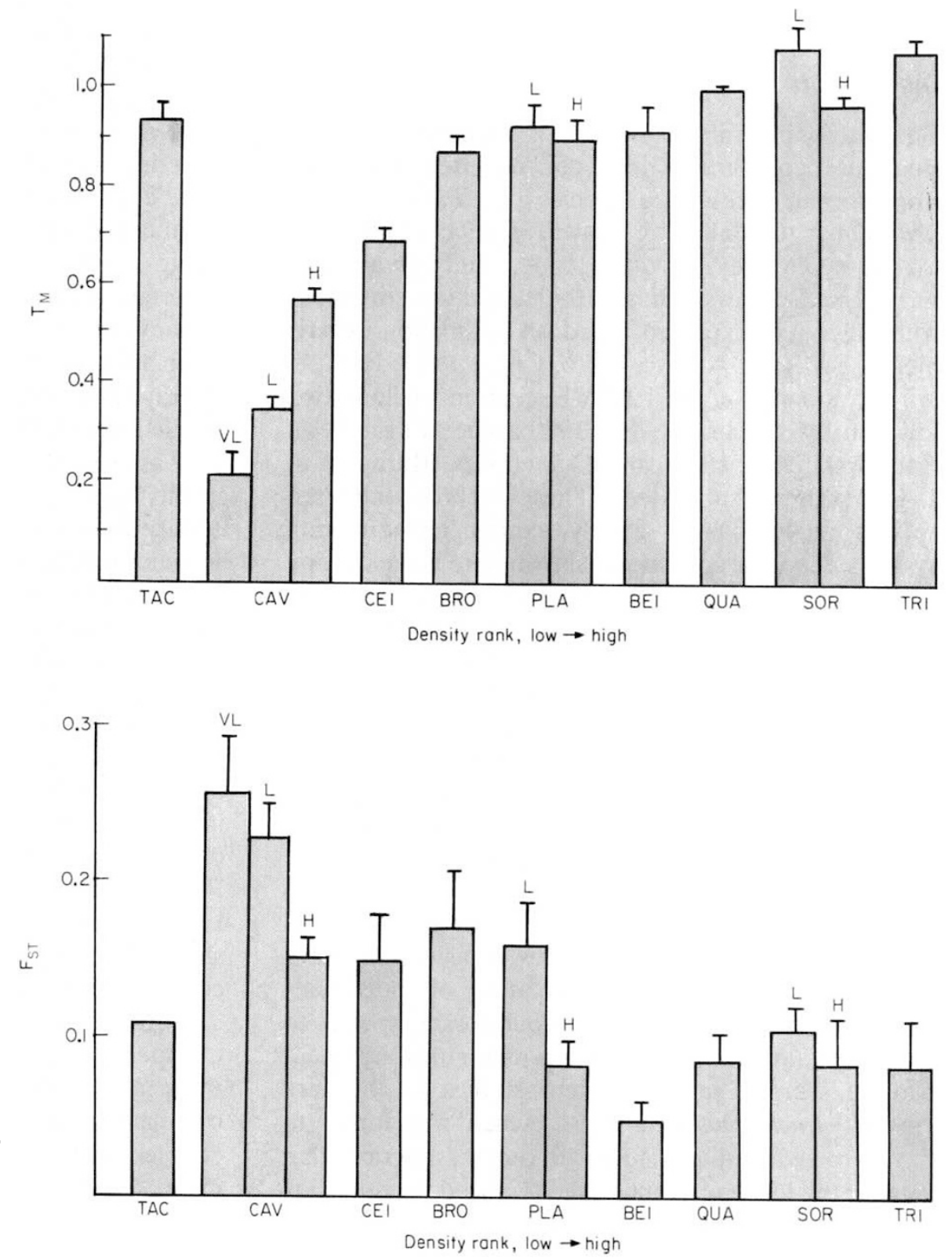
because data do not exist on the number of flowering trees for all species, but the number of trees producing fruit was used instead. Estimates of the number of flowering trees based on the number of fruiting trees is a minimum estimate because the fruiting trees may represent a fraction of the total that actually flowered. The upper limit of flowering trees should be somewhat less than the number of 'adult' size trees on the FDP. The given order of Quararibea and Beilschmedia could be as given or reversed depending on the number of trees that actually flowered. This is also true of Brosimum and Ceiba. For these species pairs the most conservative rank was used in the correlation analyses. If these pairs of species were given equal ranks or the ranks were reversed, the correlation between $F_{\mathrm{ST}}$ and flowering tree density would be higher.

\section{Discussion}

The outcrossing rates observed for most species in this study are comparable to those reported for other tropical rain forest tree species [i.e. Pithecellobium pedicellare (O'Malley \& Bawa, 1987), Bertholletia excelsa (O'Malley et al., 1988), and Quararibea asterolepis (Murawski et al., 1990)], and are consistent with the values expected based on pollination experiments (e.g. Kalin Arroyo, 1976; Chan, 1981; Bawa et al., Dayandanan et al., 1990). Exceptions include two low-density species in the Bombaceae: Cavanillesia (Murawski et al., 1990) and Ceiba (D. A. Murawski \& J. L. Hamrick, submitted). These are the only tree species analysed that clearly exhibit mixed-mating systems. Another species not shown here is the canopy tree, Dipteryx oleifera (formerly $D$. panamensis), an autotetraploid with a low density of flowering trees $\left(<0.5 \mathrm{ha}^{-1}\right)$, with a relatively low multilocus outcrossing estimate of $0.74( \pm 0.07)$ (D. A. Murawski \& J. L. Hamrick, unpublished results). Bawa et al. (1985) found that two out of three rare or uncommon hermaphroditic rain forest tree species were self-compatible as compared to the vast majority of the more common species that were self-incompatible. Given these results, one could speculate that outcrossing or underlying incompatibility systems may be relaxed in some species that occur at extremely low densities. Without this concession, the spatial isolation of individuals would constrain the ability of an outcrossing species to reproduce (Ashton, 1984). Support for this argument can be seen in mating system studies of the rare species, Eucalyptus rhodantha, which was found to have a mixed mating system with outcrossing rates that were at the low end of the range reported for relatively more common Eucalyptus species (Sampson et al.,
1989). In cultivated rye, the gametophytic incompatibility system was relaxed and outcrossing estimates were lowered at low-plant density (Vaquero et al., 1989). In that study, the low-plant density corresponded with low-pollen density during fertilization. Alternatively, one could speculate that trees at high densities may have higher outcrossing rates due to selfincompatibility systems, pollen competition (e.g. Bertin, 1982; Snow \& Mazer, 1988), and/or the selective abortion of selfed progeny (as in Murneek, 1954; Sarvas, 1962, 1968).

Heterogeneity of pollen allele frequencies received by maternal trees can be caused by factors such as family structure, different flowering schedules of individual trees, or any factor that leads to variation in pollinator behaviour at different trees, such as shifting schedules of nectar production (e.g. Frankie \& Haber, 1983). Given the spatial scale and tree densities (Table 3 ) of this study, it seems unlikely that family structure is an important source of heterogeneity in pollen allele frequencies among maternal trees. Information on flowering schedules of a few of the study species (e.g. for Platypodium, Sorocea, Cavanillesia; Murawski, unpublished data) would indicate that differences in timing of flowering of individual trees may be an important factor, as would the degree of isolation of individuals (e.g. Cavanillesia; Murawski et al., 1990).

An allozyme analysis of mating systems, such as that employed for these species, provides a basis for a more detailed examination of the species' mating behaviour. The association of pollen allele frequency heterogeneity experienced by maternal trees with population density indicates that trees at low adult population densities tend to mate with fewer pollen donors (correlated matings) than trees at high adult densities. The usual conclusion, that most non-random mating is among near neighbours, reduces effective population sizes. However, as Hamrick \& Murawski (1990) have noted, heterogeneity in pollen allele frequencies can occur without a predominance of near-neighbour matings. Asynchronous flowering and interplant incompatibilities can greatly modify the breeding structure of the population and the effective population size. Furthermore, Hamrick \& Murawski (1990) and M. D. Loveless and J. L. Hamrick (in preparation) have shown that long distance pollen movement is relatively common for two of our study species (Platypodium and Tachigali) increasing apparent population sizes. Thus, it appears that the breeding structure of low density tropical trees may consist of a large proportion of correlated matings (either due to time or space) coupled with substantial long distance pollen movement (Hamrick \& Murawski, 1990). Moreover, to measure effective population size adequately and its 
effect in genetic structure, one would need to know the life-time mating patterns of individual trees. This need is obvious in view of the among-year variation in pollen composition found among maternal trees of Cavanillesia and Platypodium (Murawski et al., 1990).

Earlier authors differed in respect to their view of the levels of gene flow and the importance of drift in tropical tree evolution (e.g. Baker, 1959; Federov, 1966; Ashton, 1969; Bawa, 1974). If gene flow is limited and if most matings occur among relatively few individuals, most tropical tree populations should lose genetic variation due to random genetic drift. A comparison of allozyme diversity of common and uncommon tree species on Barro Colorado Island showed that uncommon species were less polymorphic on a per capita basis than the common species (Hamrick et al., 1991; Hamrick \& Murawski, 1991). Thus, it is possible that the lower polymorphism of the uncommon species is the result of genetic drift brought on by reduced numbers of pollen donors. On the other hand, the uncommon species analysed by Hamrick \& Murawski (1991), maintained higher levels of genetic diversity than would be predicted based on the number of adults on the FDP. Once again, breeding systems that combine significant levels of correlated mating with long distance gene flow could explain these apparent inconsistencies.

The breeding systems of these tropical trees may represent a complex and variable mixture of correlated matings and long distance pollen movement. Our results indicate that the density of flowering individuals plays a significant role in shaping the breeding structure with low-density species apparently having fewer pollen donors. Among-tree pollen dispersal distances may, on the other hand, be much greater for these species (Hamrick \& Murawski, 1990) partially compensating for the higher rates of correlated matings. Conversely, higher density species seem to have more random mating but pollen dispersal distances may be less. These speculations are consistent with what little is known of pollen movement in tropical plant populations (Hamrick \& Murawski, 1990; Webb \& Bawa, 1983; Murawski, 1987).

\section{Acknowledgements}

We are especially grateful to S. Hubbell and R. Foster for the use of the Forest Dynamics Plot on Barro Colorado Island and to $\mathrm{K}$. Ritland for supplying the mating system program (updated version, August, 1990). This work was supported by N.S.F. grants BSR8600083 and BSR8918420 and an Andrew Mellon Foundation Grant; administered by the
Smithsonian Institution, to JLH. The staff of the Smithsonian Tropical Research Institute assisted with facilities and logistical support in Panama.

\section{References}

ASHTON, P. s. 1969. Speciation among tropical forest trees: some deductions in the light of recent evidence. Biol. J. Linn. Soc. London, 1, 155-196.

ASHTON, P. s. 1984. Biosystematics of tropical woody plants: a problem of rare species. In: Grant, W. F. (ed.), Plant Systematics, Academic Press, New York.

Ashton, P. S. 1988. Dipterocarp biology as a window to the understanding of tropical forest structure. Ann. Rev. Ecol. Syst., 19, 347-370

BAKER, H. G. 1959. Reproductive methods as factors in speciation in flowering plants. Cold Spring Harbor Symp. Quant. Biol., 24, 177-191.

BAKER, H. G. AND HARRIS, B. J. 1959. Bat-pollination of the silkcotton tree, Ceiba pentandra (L.) Gaertn. (sensu lato), in Ghana. J. W. Af. Sci. Assoc., 5, 1-9.

BAWA, K. S. 1974. Breeding systems of tree species of a lowland tropical community, Evolution, 28, 85-92.

BAWA, K. S., PERRY, D. R. AND BEACH, J. H. 1985. Reproductive biology of tropical lowland rain forest trees. I. Sexual systems and incompatibility mechanisms, Am. J. Bot., 72, 331-345.

BERTIN, R. I. 1982. Paternity and fruit production in trumpet creeper (Campsis radicans). Am. Nat., 119, 694-709.

CARVALHO, C. T. DE. 1960. Das visitas de morcegos as flôres (Mammalia: Chiroptera). Anais Acad. Brasil. Cienc., 32, 359-377.

CHAN, H. T. 1981. Reproductive biology of some Malaysian dipterocarps. III. Breeding systems. Malays. For., 44, 28-36.

DAYANANDAN, S., ATTYGaLlA, D. N. C., ABEYGUNASEKERA, A. W. W. L., GUNATILleke, I. A. U. N. AND GUNATILlEKE, C. V. S. 1990. Phenology and floral morphology in relation to pollination of some Sri Lankan dipterocarps. In: Bawa, K. and Hadley, M. (eds), Reproductive Ecology of Tropical Forest Plants. UNESCO, Paris and Parthenon Publishing Group, Carnforth U. K. (in press).

Ellstrand, N. C., TORRES, A. M. AND LEvin, D. A. 1978. Density and the rate of apparent outcrossing in Helianthus annuus (Asteraceae). Syst. Bot. 3, 403-407.

FEDEROV, A. A. 1966. The structure of the tropical rain forest and speciation in the humid tropics, J. Ecology., 54, 1-11.

FRANKIE, G. W. AND HABER, W. A. 1983. Why bees move among mass flowering neotropical trees. In: Jones, C. V. and Little, R. J. (eds), Handbook of Experimental Pollination Biology. Van Nostrand Reinhold, New York. pp. 360-372. HAMRICK, J, L., GODT, M. J., MURAWSKI, D. A. AND LOVELESS M. D. 1991. Correlations between species traits and allozyme diversity: implications for conservation biology. In: Flank, D. A. and Holsinger, K. E. (eds), Strategies for the ex situ Preservation of Genetic Diversity in Rare and Endangered Plant Species (in press). 
HAMRICK, J. L. AND MURAWSKI, D. A. 1990. Breeding structure of tropical tree populations. Plant Sp. Biol. (in press).

HAMRICK, J. L. AND MURAWSKI, D. A. 1991. Levels of allozyme diversity in populations of uncommon neotropical tree species. J. Trop. Ecol., 5, 157-165.

HUBBELL, S. P. AND FOSTER, R. B. 1986. Commonness and rarity in a neotropical forest: implications for tropical tree conservation. In: Soule, M. E. (ed.), Conservation Biology: The Science of Scarcity and Diversity. Sinauer Associates Inc., Massachusetts. pp. 205-231.

KALIN ARROYO, M. T. 1976. Geitonogamy in animal pollinated tropical angiosperms: a stimulus for the evolution of selfincompatibility. Taxon 25, 543-548.

KALIN ARROYO, M. T. 1979. Comments on breeding systems in neotropical forests. In: Larsen, K. and Holm-Nielsen, L. B. (eds), Tropical Botany. Academic Press, New York, pp. 371-380.

KOPTUR, s. 1984. Outcrossing and pollinator limitation of fruit set: breeding systems of neotropical Inga trees (Fabaceae: Mimosoideae). Evolution, 38, 1130-1143.

LEVIN, D. A. AND KERSTER, H. W. 1974. Gene flow in seed plants. Evol. Biol., 7, 139-220.

MURAWSKI, D. A. 1987. Floral resource variation, pollinator response, and potential pollen flow in Psiguria warscewiczii. Ecology, 68, 1273-1282.

MURAWSKI, D. A., HAMRICK, J, L., HUBBELL, S. P. AND FOSTER, R. B. 1990. Mating systems of two Bombacaceous trees of a neotropical moist forest. Oecologia, 82, 501-506.

MURNEEK, A. E. 1954. The embryo and endosperm in relation to fruit development, with special reference to the apple, Malus sylvestris. Proc. Am. Soc. Hortic. Sci., 64, 573-582.

O'MALlEY, D. M. AND BAWA, K. s. 1987. Mating system of a tropical rain forest tree species. Am. J. Bot., 74, 1143-1149.

O'MALLEY, D. M., BUCKLEY, D. P., PRANCE, G. T. AND BAWA, K. S. 1988. Genetics of Brazil nut (Bertholletia excelsa Humb. \& Bonpl.: Lecythidaceae), 2. Mating system, Theor. Appl. Genet., 76, 929-932.
RITLAND, K. 1990. A series of FORTRAN computer programs for estimating plant mating systems. J. Heredity, 81, 235-237.

RITLAND, K. AND JAIN, S. K. 1981. A model for the estimation of outcrossing rate and gene frequencies based on $n$ independent loci, Heredity, 47, 37-54.

SAMPSON, J. F., HOPPER, S. D. AND JAMES, S. H. 1989. The mating system and population genetic structure in a bird-pollinated mallee, Eucalyptus rhodantha. Heredity, 63, 383-393.

SARVAS, R. 1962. Investigations on the flowering and seed crop of Pinus sylvestris. Commun. Inst. For. Fenn., 53, 1-198.

SARVAS, R. 1968. Investigations on the flowering and seed crop of Picea abies. Commun. Inst. For Fenn., 67, 1-84.

SCHEMSKE, D. W. AND LANDE, R. 1985. The evolution of selffertilization and inbreeding in plants. II. Empirical observations. Evolution, 39, 41-52.

SHAW, D. v., KAHLER, A. L. AND ALlaRd, R. w. 1981. A multilocus estimator of mating system parameters in plant populations. Proc. Natl. Acad. Sci. USA , 78, 1298-1302.

SNOW, A. A. AND MAZER, S. J. 1988. Gametophytic selection in Raphanus raphanistrum: a test for heritable variation in pollen competitive ability Evolution, 42, 1065-1075.

SOLTIS, D. E., HAUFLER, C. H., DARROW, D. C. AND GASTONY, G. J. 1983. Starch gel electrophoresis of ferns: a complication of grinding buffers, gel and electrode buffers, and staining schedules, Am. Fern J., 73, 9-15.

TOLEDO, v. M. 1977. Pollination of some rainforest plants by non-hovering birds in Veracruz, Mexico. Biotropica, 9, 262-267.

VAQUERO, F., VENCES, F. J., GARCIA, P., RAMIREZ, L. AND PEREZ, M. 1989. Mating systems in rye: variability in relation to the population and plant density. Heredity, 62, 17-26.

WEBB, C. J. AND BAWA, K. S. 1983. Pollen dispersal by hummingbirds and butterflies: a comparative study of two lowland tropical plants. Evolution, 37, 1258-1270. 